\title{
An Analysis of the Professional Competencies of Turkish Language and Literature Teachers on the Basis of the Ability of Using and Managing Technology
}

\author{
Emine YağCl ${ }^{1 *}$, Ahmet Güneyli ${ }^{1}$ \\ ${ }^{1}$ Near East University, CYPRUS \\ Received 18 November 2017 - Revised 23 April 2018 - Accepted 12 May 2018
}

\begin{abstract}
The purpose of this study is to reveal the importance of technology in education and to explore the professional competencies of Turkish language and literature teachers on the basis of usage and management of technology skills. In the quantitative dimension of this study, the significant difference between the opinions of Turkish language and literature teachers on the necessity of technology and their personal characteristics were examined. The qualitative dimension, on the other hand, investigated whether school managers emphasised technology usage and management skills in their expectations of Turkish language and literature teachers. The problem sentence of the study is therefore "what are the professional competencies of Turkish and literature teachers on the basis of usage and management of technology skills?" This study examines both teachers $(n=99)$ and school managers $(n=26)$ who worked at the secondary education level in Cyprus during the 2017-2018 academic year. A questionnaire was prepared by the researchers with the purpose of determining the technology usage status of teachers and the extent to which they believe that using technology is necessary. A semi-structured interview form was prepared in order to determine the expectations of school managers from Turkish language and literature teachers and their professional competencies. In order to be able to analyse quantitative data in the study, frequencies and percentages were used, which are descriptive statistics. Additionally, the chi-square test was applied in order to determine whether there were any differences in the answers given by teachers according to the independent variables. Content analysis was conducted in order to analyse the qualitative data. Based on the findings of the study, it can be said that teachers must accept the reality that even though they agree that technology is necessary, this opinion in fact has no value as technology is still not used. The expectations of school managers from language and literature teachers were evaluated and only a limited number of managers (only 1 student out of 26) emphasised that teachers should be competent in using technology.
\end{abstract}

Keywords: language and literature education, technology based language education, teachers professional competences, school managers opinions about technology usage, secondary school, Cyprus

\section{INTRODUCTION}

Knowledge is obtained more easily and rapidly today with the development of information technologies. Expanding rapidly to all sectors, Information technologies have also begun to be used in education (Dias Caetano \& Nogueira do Nascimento, 2017; Sinchi Barbecho, Torres Pineda, \& Alvarado Salinas, 2017). Used in education, schools and classrooms, information technologies bear considerable importance from the viewpoint of teachers

(C) 2018 by the authors; licensee Modestum Ltd., UK. This article is an open access article distributed under the terms and conditions of the Creative Commons Attribution License (http://creativecommons.org/licenses/by/4.0/). \emineyagci737@yahoo.com (*Correspondence) $\bigotimes$ ahmet.guneyli@neu.edu.tr 


\section{Contribution of this paper to the literature}

- Study includes the description of the current situation in Northern Cyprus regarding the use of technology by teachers teaching in Turkish Language and Literature.

- Turkish Language and Literature teachers and the school administrators views are taken into account to conduct an unbiased in depth analysis regarding their perceptions on Turkish Language and Literature teachers usage of technology.

- Both qualitative and quantitative studies are carried out to evaluate teachers' use of technology; additionally teachers' self-criticism regarding the use of technology, and the school administrators' critical point of view in regards to Turkish Language and Literature teachers usage of technology.

(Lawrence, 2018; Pala, 2006). Teachers today are faced with a student profile that uses information technologies with ease and mastery. For this reason, teachers must improve themselves in the field of technology. If teachers fail to improve their technology usage abilities, they cannot adapt to the improving and changing education systems. They can experience difficulty in teaching students with traditional methods and techniques in the changing education system (Aksoy, 2003; Osmani, Hindi \& Weerakkody, 2018). In this context, teachers must first accept the changing technology and then they must develop and use their knowledge and technology skills. Additionally, teachers must guide students in the field of technology.

Having teachers who are interested, knowledgeable and skilful in the field of technology is not sufficient. Schools must be able to facilitate access to technological sources and manage technology effectively (Balc1, 2001; Başaran, 2000; Petko, Prasse and Cantieni, 2018). People who undertake management responsibility in education must make use of information and communication technology in the operation process of the school (Evans, 1970). The leadership and management strategies of school managers are extremely important in the effective usage of technology in schools (Weng \& Tang, 2014). However, school managers who bear the responsibility of making decisions in technology-management ae majority of schools today lack the required knowledge and skills in information and communication technologies. Thus, they are not prepared to act as technological leaders in schools (Shiller, 2003). School managers have to take several decisions regarding education. These decisions increase the quality of the school when they are associated with technological infrastructure, equipment and skills (Salimi \& Ghonoodi, 2012). Telem (1999) demonstrated a plan in the process of integrating information and communication technologies in institutions. This plan consisted of five sections, namely psychological, technical, structural, toolsvalues and managerial. The changes that occur in this direction have to pass through a process that requires attention (Yuen, Law \& Wang, 2003).

Today, managers who have the capability to bring technology into schools are extremely valuable. School managers who are able to use and manage the technology well in the school and ensure that other people can also effectively use the existing technologies are called "technology leaders" (Can, 2003; Kearsley \& Lynch, 1992; Shyr, 2017). A school manager who is also a technology leader must first provide opportunities to teachers, employees and students to use technology under equal terms in the school environment (Flanagan \& Jacobsen, 2003). At schools, not only school managers but also teachers have to be technology leaders (Lin, 2016). In particular, school managers who are also technology leaders must control the usage of technology in activities inside and outside the classroom.

Mooij and Smeets (2001) listed five stages in the process of integrating information and communication technologies into school, which are:

1. Ensuring that all teachers access technology,

2. Demonstrating the importance of using technology in all departments and units of the school,

3. Emphasising the essence of information and communication technologies in developing new ideas,

4. Having adequate information and communication technologies equipment,

5. Incorporating technology usage in teaching and learning processes.

Technology usage, which is important for all modern courses, has become the most important instrument for accessing information. The use of technology is also highly critical in Turkish and literature teaching (Baki \& Karakuş, 2012). Computers, smart boards, slides, and all kinds of audio-visual technological devices have claimed their place in the education process. This development and change has also affected Turkish courses. Today, the use of technological devices and materials in language teaching has become a necessity as it is observed that traditional methods and techniques are no longer satisfactory (Özbay, 2015; Nurova, Kharisov, Kharisova \& Aitova, 2017).

The devices and instruments which will be used in Turkish and literature courses must have certain characteristics (Akyol, 2007). For example, these technological devices must be chosen according to the individual 
characteristics of students and the content of the course. Studies conducted by several researchers (Durukan, 2011; Melo, Mendez Batres \& Martinell, 2017; Rodríguez, 2018) have emphasized the benefits of technology-assisted language and literature teaching, as follows:

1. It is a student-centred teaching approach. It ensures that students are active throughout the learning process and facilitates learning.

2. Facilitating the usage of multiple methods and techniques, it enriches learning.

3. As it addresses multiple senses of students, it ensures that learning is easier and more permanent.

4. It transfers difficult situations that cannot be easily reached by students into the learning environment and thus enables learning.

5. It guides students towards cooperative learning.

6. It enables the repetition of any topic.

7. As knowledge is transferred more systematically in a shorter period of time, teaching becomes more efficient. Learning occurs more rapidly.

According to the research findings of Yaman (2007), pre-service teachers think that technology usage makes a significant contribution to the permanency of learning in Turkish classes, the increase in the interest of students in the class, the understanding of students on covered topic, their enjoyment of the Turkish class, the development and improvement of listening skills, and the attainment of targets related to the given lesson. On the other hand, some pre-service teachers who participated in the study stated that, contrary to the positive aspects of technology, it can affect the speaking and writing skills of students negatively. The studies conducted by Şahin and Akçay (2011) and Altınok (2011) indicated that most of the Turkish language and literature teachers included in their study displayed positive attitudes towards the use of technology. Özbay (2003) claimed that education technologies such as tape recorders, radios, televisions, computers, videos and cassettes had a considerable impact on the speaking skills of students. Teachers can set an example to their students by using these instruments in language and literature courses thereby improving the students' spoken language. It is widely acknowledged that Turkish language teachers predominantly use coursebooks in their classes. A limited number of teachers make use of technological devices in order to exploit the positive effects of these instruments. It has been shown that only $4.53 \%$ of teachers used audio-visual instruments during classes, whereas $94.44 \%$ of teachers used coursebooks. Durukan's study (2011) determined that, compared to the Turkish grammar classes delivered with traditional methods, computer-assisted grammar teaching was more successful. Computer-assisted grammar teaching affected student success in a positive direction and mistakes in certain concepts decreased. Önkaş (2010) stated that technologyassisted language and literature teaching is more effective and permanent compared to traditional teaching methods. Preparing Turkish coursebooks with CD appendixes can make the teaching of speaking skills more effective. Additionally, technology saves teachers the time they lose while writing on the board and allows students to perform more practice in the topics in which they are instructed.

Durmuşçelebi (2007) examined the education, curriculum and coursebooks in the native language in a comparison of Turkey and Germany, reaching the conclusion that technology is underutilized. It was recommended that necessary arrangements should be made to support the content of Turkish course books with technological devices such as CDs, VCDs, computers and the Internet. However, several educationists (Akkoyunlu \& Soylu, 2011; Kabadayı, 2006; Öner, 2006; Temur \& Vuruş, 2009; Yaman \& Erdoğan, 2007; Yıldırım \& Tahiroğlu, 2006) stated that in technological communities, the orthographic rules, sentence and word structures and phonetic features of Turkish language are disregarded, and that Turkish is used carelessly and incorrectly. It was underlined that this problem should be addressed with care.

Arslan's study (2008) did not indicate any significant difference in terms of the computer usage of Turkish teachers based on their gender, seniority or education level. In the quantitative dimension of this study, the correlation between the opinions of Turkish and literature teachers on the necessity of technology and their personal characteristics were examined. The qualitative dimension, on the other hand, investigated whether school managers emphasised technology usage and management skills in their expectations of Turkish and literature teachers. Therefore, the purpose of this study is to reveal the importance of technology in education and to explore the professional competencies of Turkish and literature teachers on the basis of usage and management of technology skills. The problem sentence of the study is therefore "what are the professional competencies of Turkish and literature teachers on the basis of usage and management of technology skills?" Based on this problem sentence, the following sub-problems are formulated 


\section{SUB-PROBLEMS IN QUANTITATIVE RESEARCH DIMENSION}

Is there any significant difference between the opinions of Turkish and literature teachers on the following items on the basis of their personal characteristics including gender, age, nationality, education level, seniority, location of the school and union membership status?

1. Being equipped with skills that a modern teacher should possess (computer, Internet ...)

2. Effective, proper and accurate employment of teaching-learning strategies, methods, techniques and tactics in the learning-teaching environment,

3. Implementing multiple learning environments in the school which improve learning-oriented interaction among students and between teachers and students,

4. Implementing multiple learning environments outside the school which improve learning-oriented interaction among students and between teachers and students,

5. Directing students towards the use of diverse materials and resources.

\section{SUB-PROBLEMS IN QUALITATIVE RESEARCH DIMENSION}

What are the expectations of school managers of Turkish and literature teachers (in professional, personal terms, etc.)? Do the school managers expect language and literature teachers to be competent in using and managing technology?

\section{METHOD}

In this study, a mixture method including both qualitative and quantitative techniques has been employed. Quantitative studies examine social events by means of statistical analysis of numeric data, display cause and effect relationships, and attempt to find the rules of social systems. In other words, they are studies which collect data from broad sample groups, statistically analyse them in order to test hypotheses and attempt to generalise the obtained data (Bogdan \& Biklen, 2006). On the other hand, the purpose of a qualitative study is to obtain a holistic picture instead of making generalisations. Qualitative studies attempt to examine a subject in detail and depth (Glesne, 2011). Qualitative studies have such features as perceiving and revealing events in their natural habitat with a holistic viewpoint, performing an inductive analysis, and adding flexibility to the study (Maxwell, 1996; Miles \& Huberman, 1994).

The mixed research method is an approach which is based on mutual completion of qualitative and quantitative methods in terms of "depth and detail" and "generalisation and estimation" dimensions and offers the researchers a variety of options (Yıldırım \& Şimşek, 2013; Johnson, Onwuegbuzie \& Turner, 2007). The mixed research method is more than just a combination of qualitative and quantitative. It is a harmonisation effort that is used so that the strengths of both research methods can support each other. With this method, reaching the research findings becomes considerably easier for the researcher (Creswell \& Plano Clark, 2007).

The research is based on a case study, which is a qualitative research model. In case studies, factors related to a given case are examined in detail. An attempt is made to determine how these factors affect the case examined in the study and how they are affected by the case at hand (Glesne, 2011; Yıldırım \& Şimşek, 2011). The quantitative dimension of the study, on the other hand, is based on a screening model. The screening model aims to describe a case as it is. An attempt is made to define the event, individual or object which is subject of the study in its own conditions and as it is. There is no attempt to change or affect them in any way whatsoever. The important thing is the ability to observe and determine the subject being examined (Karasar, 2015).

\section{STUDY GROUP}

This study examines both teachers and school managers. No sample was taken in the quantitative dimension of the study and an attempt was made to reach the Turkish language and literature teachers who worked at the secondary education level in Cyprus during the 2017-2018 academic year (universe). Some teachers were not willing to answer the questionnaires. Some teachers could not be reached because the researchers could not find them in the school on the day of their visit. Resultantly, the quantitative dimension of the research consisted of 99 Turkish language and literature teachers. Demographic data on the teachers who participated in the study can be observed in Table 1. 
Table 1. Distribution of teachers according to their indicative information

\begin{tabular}{lll}
\hline & Number (n) & Percentage (\%) \\
\hline Gender & 80 & 80.81 \\
\hline Female & 19 & 19.19 \\
\hline Male & & \\
\hline Age group & 26 & 26.26 \\
\hline 39 years and below & 34 & 34.34 \\
\hline $40-45$ years & 39 & 39.39 \\
\hline 46 years and above & & \\
\hline Nationality & 75 & 75.76 \\
\hline North Cyprus & 24 & 24.24 \\
\hline North Cyprus and Turkey & & \\
\hline Education Level & 81 & 81.82 \\
\hline Undergraduate & 18 & 18.18 \\
\hline Graduate & & \\
\hline Experience & 51 & 51.52 \\
\hline 15 years or below & 48 & 48.48 \\
\hline 16 years or above & & 78.79 \\
\hline School & 78 & 21.21 \\
\hline City & 21 & \\
\hline Rural & & 74.75 \\
\hline Union & 74 & 25.25 \\
\hline Member & 25 & \\
\hline Not member & & \\
\hline & & \\
\hline
\end{tabular}

Table 2. Distribution of school managers according to their indicative information

\begin{tabular}{lcl}
\hline & Number $(\mathbf{n})$ & Percentage (\%) \\
\hline Gender & 12 & \\
\hline Female & 13 & 48 \\
\hline Male & & 52 \\
\hline Age group & 7 & 28 \\
\hline $45-49$ years & 18 & 62 \\
\hline 50 years and above & & 73,1 \\
\hline Education Level & 19 & 26.9 \\
\hline Undergraduate & 7 & \\
\hline Graduate & & 3.8 \\
\hline Experience & 1 & 96.2 \\
\hline 20 years or below & 25 & \\
\hline 21 years or above & & \\
\hline
\end{tabular}

An examination of Table 1 shows that $80.81 \%$ of the teachers who participated in the study were female and $19.19 \%$ were male, $26.26 \%$ were 39 years of age or under, $34.34 \%$ were between 40 and 45 years of age, $39.39 \%$ are were 46 years or older, $75.76 \%$ were nationals of Northern Cyprus only and $24.24 \%$ were nationals of both Northern Cyprus and Turkey. It can be seen that $81.82 \%$ of the teachers have undergraduate degree, $18.18 \%$ have graduated degrees, $51.52 \%$ had15 years of experience or less, whereas $48.48 \%$ have 16 or more years of experience in the profession. It was also found that $78.79 \%$ of the teachers who participated in the study worked in urban areas, whereas $21.21 \%$ worked at schools located in rural area. Finally, it can be seen $74.75 \%$ of teachers were members of a union.

Purposive sampling and convenience case sampling methods were used in the process of identifying the school managers who would participate in the study. Researchers made the effort to interview the managers of the schools that they visited in order to conduct the questionnaire study with teachers. Thus, the research gained speed, practicality and economy, and data were collected from the most accessible school manager group. Demographic information on the school managers who participated in the study is given in Table 2.

An examination of Table 2 shows that $48 \%$ of the school managers who participated in the study were female and $52 \%$ were men, $28 \%$ were in the $45-49$ age interval, and $62 \%$ are 50 years of age or older. It can also be seen that $73.1 \%$ of the school managers have undergraduate degrees and $26.9 \%$ have graduate degrees, $3.8 \%$ have 20 years or less professional experience and $96.2 \%$ have 20 years or more of professional experience. When the school managers were asked about their undergraduate field of study, it was found that nine graduated from social 
sciences, eight graduated from natural sciences, three graduated from foreign language, two graduated from art, one graduated from sports and one graduated from management.

\section{DATA COLLECTION TOOLS}

In order to generate the quantitative data of the study, a personal information form was used to obtain demographic information on the Turkish language and literature teachers. In this form, questions were asked on gender, age, nationality, level of education, experience, the location of the school and union membership.

A questionnaire was prepared by the researchers with the purpose of determining the technology usage status of teachers and the extent to which they believe that using technology is necessary. A literature review was conducted in order to ensure the scope validity of the questionnaire. Accordingly, reference was made to the articles authored by Güneyli and Özgür (2007) and Güneyli, Özgür and Zeki (2009) for the questions in the questionnaire titled "Professional Competencies of Turkish Language and Literature Teachers on the Basis of the Ability of Using and Managing Technology". Resultantly, a total of five questions were included in the questionnaire. Teachers were asked to choose the answer they felt to be appropriate from "very necessary", "necessary" , "moderately necessary", "unnecessary" and "very unnecessary" from the options in the mentioned five questions. Once the draft questionnaire form was prepared, the opinions of three experts (computer and teaching technologies, measuringevaluation and Turkish education) were obtained. After the expert opinions were received, a pilot study was conducted at a secondary education institution. The questionnaire was finalised after expert opinions were obtained and the pilot application was completed. Reliability and validity calculations were not needed because the analysis of each question in the questionnaire was performed independently and total scores were not calculated; however, the questionnaire was created taking into consideration the factors which affected reliability and validity.

A semi-structured interview form was prepared in order to determine the expectations of school managers from Turkish language and literature teachers and their professional competencies. This form was prepared by the researchers and consists of two sections. The first section consists of questions with short answers which aim to determine demographic information (gender, age, experience, undergraduate field of study, level of education). The second section of the interview form consists of open-ended questions. In order to avoid unnecessary question load on the interviewees, the number of questions was limited to five. These questions are mainly directed at exploring the expectations of school managers from Turkish language and literature teachers. In order to evaluate the validity, comprehensibility and fitness of the interview form in relation to the research problem, opinions were sought from three experts (the same experts whose opinions were sought in the questionnaire). Subsequently, a pilot application was performed with two managers and the questions were given their final version.

\section{COLLECTION AND ANALYSIS OF DATA}

In the study, an application was filed to the Academic Ethics Board at the researchers' university and a report was obtained which approved the ethical fitness of the measurement tools used. Later, permission was obtained from the Ministry of National Education in Northern Cyprus in terms of the applicability of the scale in secondary education institutions. After receiving ethical clearance and application permission, schools were visited, questionnaires were administered and interviews were conducted by researchers in person during school hours. Attention was paid to ensure participation was on a voluntary basis, and the teachers and school managers who did not want to participate in the study were not forced. The names of schools and participants were kept confidential by the researchers.

In order to be able to analyse quantitative data in the study, frequencies and percentages were used, which are descriptive statistics. Additionally, the chi-square test was applied in order to determine whether there were any differences in the answers given by teachers according to the independent variables. Separate chi-square tables were generated for each of the five questions and the findings were presented. Content analysis was conducted in order to analyse the qualitative data. The answers given by school managers were subjected to content analysis and codes were assigned; similar codes were grouped to form themes. The themes were classified to create categories. The frequency of preferring each category was stated as "frequency" and percentages were also included; in summary, qualitative data were digitalized and tabulated. In order to be able to view the themes and categories concretely, the opinions of school managers were directly included and citations were made. The names of school managers were kept confidential and codes were used (such as SP1 for school principal 1) in order to present the citations. 
Table 3. Distribution of opinions of teachers in regard to the management and use of technology in education

\begin{tabular}{lcccc}
\hline & \multicolumn{2}{c}{ Necessary } & \multicolumn{2}{c}{ Very Necessary } \\
\hline $\begin{array}{l}\text { Being equipped with skills that a modern teacher should possess (computer, } \\
\text { internet ...) }\end{array}$ & $\mathbf{n}$ & $\%$ & $\mathbf{n}$ & $\%$ \\
\hline $\begin{array}{l}\text { Effective, proper and accurate employment of teaching-learning strategies, } \\
\text { methods, techniques and tactics in the learning-teaching environment }\end{array}$ & 43 & 43.43 & 56 & 52.63 \\
\hline $\begin{array}{l}\text { Ensuring student participation at intra-school multiple learning } \\
\text { environments }\end{array}$ & 50 & 50.51 & 49 & 49.49 \\
$\begin{array}{l}\text { Ensuring student participation at extra-school multiple learning } \\
\text { environments }\end{array}$ & 60 & 60.61 & 39 & 39.39 \\
\hline Directing students towards the use of diverse materials and resources & 50 & 50.51 & 49 & 49.49 \\
\hline
\end{tabular}

Table 4. Comparison of the answers given by teachers to the proposition "Being equipped with skills that a modern teacher should possess (computer, internet ...)" based on their introductory information

\begin{tabular}{|c|c|c|c|c|c|c|}
\hline & \multicolumn{2}{|c|}{ Necessary } & \multicolumn{2}{|c|}{ Very necessary } & \multirow{2}{*}{$\mathbf{X}^{2}$} & \multirow{2}{*}{$\mathbf{P}$} \\
\hline & $\mathbf{n}$ & $\%$ & $\mathbf{n}$ & $\%$ & & \\
\hline \multicolumn{7}{|l|}{ Gender } \\
\hline Female & 29 & 36.25 & 51 & 63.75 & \multirow{2}{*}{0.225} & \multirow{2}{*}{0,635} \\
\hline Male & 8 & 42.11 & 11 & 57.89 & & \\
\hline \multicolumn{7}{|l|}{ Age group } \\
\hline 39 years and below & 10 & 38.46 & 16 & 61.54 & \multirow{3}{*}{0.096} & \multirow{3}{*}{0,953} \\
\hline $40-45$ years & 12 & 35.29 & 22 & 64.71 & & \\
\hline 46 years and above & 15 & 38.46 & 24 & 61.54 & & \\
\hline \multicolumn{7}{|l|}{ Nationality } \\
\hline North Cyprus & 27 & 33.75 & 48 & 60.00 & \multirow{2}{*}{0.249} & \multirow{2}{*}{0,617} \\
\hline North Cyprus and Turkey & 10 & 41.67 & 14 & 58.33 & & \\
\hline \multicolumn{7}{|l|}{ Education Level } \\
\hline Undergraduate & 31 & 38.27 & 50 & 61.73 & \multirow{2}{*}{0.153} & \multirow{2}{*}{0,695} \\
\hline Graduate & 6 & 33.33 & 12 & 66.67 & & \\
\hline \multicolumn{7}{|l|}{ School } \\
\hline City & 29 & 37.18 & 49 & 62.82 & \multirow{2}{*}{3.922} & \multirow{2}{*}{0,141} \\
\hline Rural & 8 & 38.10 & 13 & 61.90 & & \\
\hline \multicolumn{7}{|l|}{ Union } \\
\hline Member & 30 & 40.54 & 44 & 59.46 & \multirow{2}{*}{0.006} & \multirow{2}{*}{0,939} \\
\hline Not member & 7 & 28.00 & 18 & 72.00 & & \\
\hline
\end{tabular}

\section{FINDINGS}

The research first presents the quantitative findings in tables. Accordingly, an evaluation was made to determine whether there are any significant differences in the answers given by Turkish language and literature teachers to the five questions in the questionnaire according to their personal information. Table 3 presents the distribution of answers "very necessary" and "necessary" in regard to these questions.

An examination of Table 3 shows that $37.37 \%$ of the teachers who participated in the study answered "necessary" to the proposition "Being equipped with skills that a modern teacher should possess (computer, internet ...)" while $62.63 \%$ answered "very necessary". Furthermore, $43.43 \%$ of the teachers answered "necessary" to the proposition "Effective, proper and accurate employment of teaching-learning strategy, method, technique and tactics in learning-teaching environment", whereas $56.57 \%$ answered "very necessary". A total of $50.51 \%$ of teachers answered "necessary" to the proposition "ensuring participation of all students at intra-school multiple learning environments (seminars, conferences, panels etc...) with the teacher and other students which develop their learning-focused interaction and organizing such learning environments", whereas $49.49 \%$ answered "very necessary". It can be seen that $60.61 \%$ of the teachers answered "necessary" to the proposition "ensuring participation of all students at extra-school multiple learning environments (seminars, conferences, panels etc...) with the teacher and other students which develop their learning-focused interaction and organizing such learning environments", whereas 39.39\% answered "very necessary". Finally, 50.51\% of teachers answered "necessary" to the proposition "Directing students towards the use of diverse materials and resources", while $49.49 \%$ answered "very necessary". 
Table 5. Comparison of the answers given by teachers to the proposition "Effective, proper and accurate employment of teaching-learning strategies, methods, techniques and tactics in the learning-teaching environment" based on their introductory information

\begin{tabular}{|c|c|c|c|c|c|c|}
\hline & \multicolumn{2}{|c|}{ Necessary } & \multicolumn{2}{|c|}{ Very necessary } & \multirow{2}{*}{$\mathbf{X}^{2}$} & \multirow{2}{*}{$\mathbf{P}$} \\
\hline & $\mathbf{n}$ & $\%$ & $\mathbf{n}$ & $\%$ & & \\
\hline \multicolumn{7}{|l|}{ Gender } \\
\hline Female & 33 & 41.25 & 47 & 58.75 & \multirow{2}{*}{0.810} & \multirow{2}{*}{0.368} \\
\hline Male & 10 & 52.63 & 9 & 47.37 & & \\
\hline \multicolumn{7}{|l|}{ Age group } \\
\hline 39 years and below & 12 & 46.15 & 14 & 53.85 & \multirow{3}{*}{0.570} & \multirow{3}{*}{0.752} \\
\hline $40-45$ years & 13 & 38.24 & 21 & 61.76 & & \\
\hline 46 years and above & 18 & 46.15 & 21 & 53.85 & & \\
\hline \multicolumn{7}{|l|}{ Nationality } \\
\hline North Cyprus & 34 & 42.50 & 41 & 51.25 & \multirow{2}{*}{0.454} & \multirow{2}{*}{0.500} \\
\hline North Cyprus and Turkey & 9 & 37.50 & 15 & 62.50 & & \\
\hline \multicolumn{7}{|l|}{ Education Level } \\
\hline Undergraduate & 38 & 46.91 & 43 & 53.09 & \multirow{2}{*}{2.195} & \multirow{2}{*}{0.138} \\
\hline Graduate & 5 & 27.78 & 13 & 72.22 & & \\
\hline \multicolumn{7}{|l|}{ School } \\
\hline City & 34 & 43.59 & 44 & 56.41 & \multirow{2}{*}{0.410} & \multirow{2}{*}{0.815} \\
\hline Rural & 9 & 42.86 & 12 & 57.14 & & \\
\hline \multicolumn{7}{|l|}{ Union } \\
\hline Member & 30 & 40.54 & 44 & 59.46 & \multirow{2}{*}{0.004} & \multirow{2}{*}{0.952} \\
\hline Not member & 13 & 52.00 & 12 & 48.00 & & \\
\hline
\end{tabular}

Table 6. Comparison of the answers given by teachers to the proposition "ensuring participation of all students in intra-school multiple learning environments (seminars, conferences, panels etc...) with the teacher and other students which develop their learning-focused interaction and organizing such learning environments" based on their introductory information

\begin{tabular}{|c|c|c|c|c|c|c|}
\hline & \multicolumn{2}{|c|}{ Necessary } & \multicolumn{2}{|c|}{ Very necessary } & \multirow{2}{*}{$x^{2}$} & \multirow{2}{*}{$\mathbf{P}$} \\
\hline & $\mathbf{n}$ & $\%$ & $\mathbf{n}$ & $\%$ & & \\
\hline \multicolumn{7}{|l|}{ Gender } \\
\hline Female & 40 & 50.00 & 40 & 50.00 & \multirow{2}{*}{0.043} & \multirow{2}{*}{0.837} \\
\hline Male & 10 & 52.63 & 9 & 47.37 & & \\
\hline \multicolumn{7}{|l|}{ Age group } \\
\hline 39 years and below & 13 & 50.00 & 13 & 50.00 & \multirow{3}{*}{0.338} & \multirow{3}{*}{0.844} \\
\hline $40-45$ years & 16 & 47.06 & 18 & 52.94 & & \\
\hline 46 years and above & 21 & 53.85 & 18 & 46.15 & & \\
\hline \multicolumn{7}{|l|}{ Nationality } \\
\hline $\begin{array}{l}\text { North Cyprus } \\
\end{array}$ & 35 & 43.75 & 40 & 50.00 & \multirow{2}{*}{1.823} & \multirow{2}{*}{0.177} \\
\hline North Cyprus and Turkey & 15 & 62.50 & 9 & 37.50 & & \\
\hline \multicolumn{7}{|l|}{ Education Level } \\
\hline Undergraduate & 39 & 48.15 & 42 & 51.85 & \multirow{2}{*}{0.990} & \multirow{2}{*}{0.320} \\
\hline Graduate & 11 & 61.11 & 7 & 38.89 & & \\
\hline \multicolumn{7}{|l|}{ School } \\
\hline City & 38 & 48.72 & 40 & 51.28 & \multirow{2}{*}{2.265} & \multirow{2}{*}{0.322} \\
\hline Rural & 12 & 57.14 & 9 & 42.86 & & \\
\hline \multicolumn{7}{|l|}{ Union } \\
\hline Member & 38 & 51.35 & 36 & 48.65 & \multirow{2}{*}{0.470} & \multirow{2}{*}{0.493} \\
\hline Not member & 12 & 48.00 & 13 & 52.00 & & \\
\hline
\end{tabular}

When the chi-square analysis results given in Table 4 are examined, it is found that there is no statistically significant difference between the answers given by teachers who participated in the research to the proposition "Being equipped with skills that a modern teacher should possess (computer, internet ...)" according to their introductory characteristics $(\mathrm{p}>0.05)$. The opinions of teachers in regard to preparedness are found to be similar according to their introductory characteristics.

According to the data in Table 5, it has been found that there is no statistically significant difference between the answers given by teachers included in the research to the proposition "Effective, proper and accurate employment of teaching-learning strategies, methods, techniques and tactics in the learning-teaching environment" according to their introductory characteristics $(p>0.05)$. 
Table 7. Comparison of the answers given by teachers to the proposition "ensuring participation of all students at extra-school multiple learning environments (seminars, conferences, panels etc...) with the teacher and other students which develop their learning-focused interaction and organizing such learning environments" based on their introductory information

\begin{tabular}{|c|c|c|c|c|c|c|}
\hline & \multicolumn{2}{|c|}{ Necessary } & \multicolumn{2}{|c|}{ Very necessary } & \multirow{2}{*}{$x^{2}$} & \multirow{2}{*}{$\mathbf{P}$} \\
\hline & $\mathbf{n}$ & $\%$ & $\mathbf{n}$ & $\%$ & & \\
\hline \multicolumn{7}{|l|}{ Gender } \\
\hline Female & 48 & 60.00 & 32 & 40.00 & \multirow{2}{*}{0.064} & \multirow{2}{*}{0.800} \\
\hline Male & 12 & 63.16 & 7 & 36.84 & & \\
\hline \multicolumn{7}{|l|}{ Age group } \\
\hline 39 years and below & 14 & 53.85 & 12 & 46.15 & \multirow{3}{*}{2.030} & \multirow{3}{*}{0.362} \\
\hline $40-45$ years & 19 & 55.88 & 15 & 44.12 & & \\
\hline 46 years and above & 27 & 69.23 & 12 & 30.77 & & \\
\hline \multicolumn{7}{|l|}{ Nationality } \\
\hline North Cyprus & 44 & 55.00 & 31 & 38.75 & \multirow{2}{*}{0.487} & \multirow{2}{*}{0.485} \\
\hline North Cyprus and Turkey & 16 & 66.67 & 8 & 33.33 & & \\
\hline \multicolumn{7}{|l|}{ Education Level } \\
\hline Undergraduate & 47 & 58.02 & 34 & 41.98 & \multirow{2}{*}{1.243} & \multirow{2}{*}{0.265} \\
\hline Graduate & 13 & 72.22 & 5 & 27.78 & & \\
\hline \multicolumn{7}{|l|}{ School } \\
\hline City & 45 & 57.69 & 33 & 42.31 & \multirow{2}{*}{3.009} & \multirow{2}{*}{0.222} \\
\hline Rural & 15 & 71.43 & 6 & 28.57 & & \\
\hline \multicolumn{7}{|l|}{ Union } \\
\hline Member & 12 & 48.00 & 13 & 52.00 & \multirow{2}{*}{1.308} & \multirow{2}{*}{0.253} \\
\hline Not member & 47 & 63.51 & 27 & 36.49 & & \\
\hline
\end{tabular}

Table 8. Comparison of the answers given by teachers to the proposition "Directing students towards the use of diverse materials and resources" based on their introductory information

\begin{tabular}{|c|c|c|c|c|c|c|}
\hline & \multicolumn{2}{|c|}{ Necessary } & \multicolumn{2}{|c|}{ Very necessary } & \multirow{2}{*}{$\mathbf{x}^{2}$} & \multirow{2}{*}{$\mathbf{P}$} \\
\hline & $\mathbf{n}$ & $\%$ & $\mathbf{n}$ & $\%$ & & \\
\hline \multicolumn{7}{|l|}{ Gender } \\
\hline Female & 41 & 51.25 & 39 & 48.75 & \multirow{2}{*}{0.093} & \multirow{2}{*}{0.761} \\
\hline Male & 9 & 47.37 & 10 & 52.63 & & \\
\hline \multicolumn{7}{|l|}{ Age group } \\
\hline 39 years and below & 11 & 42.31 & 15 & 57.69 & \multirow{3}{*}{1.690} & \multirow{3}{*}{0.430} \\
\hline $40-45$ years & 20 & 58.82 & 14 & 41.18 & & \\
\hline 46 years and above & 19 & 48.72 & 20 & 51.28 & & \\
\hline \multicolumn{7}{|l|}{ Nationality } \\
\hline North Cyprus & 36 & 45.00 & 39 & 48.75 & \multirow{2}{*}{0.777} & \multirow{2}{*}{0.378} \\
\hline North Cyprus and Turkey & 14 & 58.33 & 10 & 41.67 & & \\
\hline \multicolumn{7}{|l|}{ Education Level } \\
\hline Undergraduate & 41 & 50.62 & 40 & 49.38 & \multirow{2}{*}{0.002} & \multirow{2}{*}{0.962} \\
\hline Graduate & 9 & 50.00 & 9 & 50.00 & & \\
\hline \multicolumn{7}{|l|}{ School } \\
\hline City & 39 & 50.00 & 39 & 50.00 & \multirow{2}{*}{2.265} & \multirow{2}{*}{0.322} \\
\hline Rural & 11 & 52.38 & 10 & 47.62 & & \\
\hline \multicolumn{7}{|l|}{ Union } \\
\hline Member & 40 & 54.05 & 34 & 45.95 & \multirow{2}{*}{0.038} & \multirow{2}{*}{0.846} \\
\hline Not member & 10 & 40.00 & 15 & 60.00 & & \\
\hline
\end{tabular}

According to Table 6, it has been found that there is no statistically significant difference between the answers given by teachers included in the research to the proposition "ensuring participation of all students at intra-school multiple learning environments (seminars, conferences, panels etc...) with the teacher and other students which develop their learning-focused interaction and organizing such learning environments" according to their introductory characteristics ( $p>0.05$ ).

According to Table 7, it has been found that there is no statistically significant difference between the answers given by teachers included in the research to the proposition "ensuring participation of all students at extra-school multiple learning environments (seminars, conferences, panels etc...) with the teacher and other students which develop their learning-focused interaction and organizing such learning environments" according to their introductory characteristics $(\mathrm{p}>0.05)$. 
Table 9. Expectations of school managers from Turkish language and literature teachers and their opinions concerning technology usage and management abilities

\begin{tabular}{|c|c|c|c|}
\hline MAIN THEME & THEME & $\mathbf{N}$ & $\%$ \\
\hline $\begin{array}{l}\text { Raising students who have the } \\
\text { knowledge, skills and affective } \\
\text { acquisitions targeted in language } \\
\text { and literature education }\end{array}$ & $\begin{array}{l}\text { Student with developed language skills }(N=15) \\
\text { Student who loves language and literature }(N=7) \\
\text { Student who has a good command of grammar rules }(N=4) \\
\text { Student who learned the topic-content in the curriculum }(N=2) \\
\text { Student with rich vocabulary }(N=1)\end{array}$ & 29 & 43.28 \\
\hline $\begin{array}{l}\text { Possessing the professional and } \\
\text { personal competencies required as } \\
\text { a Turkish language-literature } \\
\text { teacher }\end{array}$ & $\begin{array}{l}\text { Teacher who is a role model for his/her students in language-literature } \\
\text { knowledge, accumulation and awareness }(N=7) \\
\text { Teacher who has good communication with his/her students, who guides } \\
\text { and helps them }(N=3) \\
\text { Teacher who innovates and improves himself }(N=2) \\
\text { Teacher with teamwork skills }(N=2) \\
\text { Teacher with work discipline }(N=2) \\
\text { Teacher who is successful at class management }(N=1)\end{array}$ & 17 & 25.37 \\
\hline $\begin{array}{l}\text { Raising language and literature } \\
\text { students who are sensitive towards } \\
\text { their country, the people around } \\
\text { them, culture and art }\end{array}$ & $\begin{array}{l}\text { Transforming language-literature education into art education }(N=4) \\
\text { Raising caring and considerate students }(N=3) \\
\text { Raising students who love and appreciate their country }(N=2) \\
\text { Raising students who are active in cultural activities }(N=2)\end{array}$ & 11 & 16.42 \\
\hline $\begin{array}{l}\text { Realising technology-assisted and } \\
\text { student-oriented language and } \\
\text { literature education }\end{array}$ & $\begin{array}{l}\text { Performing student-centred education }(N=2) \\
\text { Performing extra-class activities }(N=1) \\
\text { Utilizing technology in classes }(N=1) \\
\text { Making classes more enjoyable }(N=1)\end{array}$ & 5 & 7.46 \\
\hline $\begin{array}{l}\text { Raising language and literature } \\
\text { students who have high-level } \\
\text { thinking skills }\end{array}$ & $\begin{array}{l}\text { Student with creativity }(N=2) \\
\text { Student with research skills }(N=1) \\
\text { Student with discussion-interpretation power }(N=1) \\
\text { Student with effective communication skills }(N=1)\end{array}$ & 5 & 7.46 \\
\hline & Total & 67 & 100 \\
\hline
\end{tabular}

When the chi-square results given in Table 8 are examined, it is found that that there is no statistically significant difference between the answers given by teachers to the proposition "Directing students towards the use of diverse materials and resources" according to their introductory characteristics $(p>0.05)$.

The qualitative findings of the study are presented in Table 8. The expectations of school managers who participated in the study from Turkish language and literature teachers and particularly their opinions on the abilities of teachers in using and managing technology are evaluated and tabulated.

When the opinions of school managers given in Table 9 are evaluated, it can be seen that the emphasis is particularly on raising qualified students. Emphasis was placed on the necessity of having curricula which equip students with cognitive and emotional. acquisitions (43.28\%), sensitiveness towards their culture, environment and art $(16.42 \%)$ and high-level thinking abilities $(7.46 \%)$. On the other hand, the qualifications of teachers were also emphasised by school managers (25.37\%). School managers claimed that language and literature teachers have to be qualified in personal and professional terms. Finally, it was identified that technology-assisted and studentoriented language and literature education should be delivered $(7.46 \%)$, which is the fundamental topic of this study.

The opinions of school managers in regard to "Raising students who have the knowledge, skills and affective acquisitions targeted in language and literature education" are as follows:

\footnotetext{
"I expect that they improve the speaking language of their students, encourage then to read, and raise students who can interpret, write and convey their ideas to others" SP 23 (Student with developed language skills)
"I would expect that the teacher particularly focuses on using Turkish language accurately and effectively, has a passion for literature, and makes students understand that life itself is literature" SP 14 (Student with love of language-literature)
}

"He must teach students how to use Turkish accurately" SP 20 (Student with good command of grammar rules) 
"I would expect that teachers know how to share knowledge and make the effort to help their students." SP 26 (Topic in the programme-student who learned the content)

"I expect that teachers will teach their students how they can use Turkish words. I expect that they encourage students to use Turkish words instead of foreign words." SP 7 (Student with rich vocabulary)

The opinions of school managers in regard to "Possessing the professional and personal competencies required as a Turkish language-literature teacher" are as follows:

"I expect that teachers will be good readers themselves so that they can instil the love of reading in their students." SP 9 (Teacher who is a role model for his/her students in language-literature knowledge, accumulation and awareness)

"I expect them to be patient and guiding when they are delivering the Turkish language and literature course to the new generation of students" SP 19 (Teacher who has good communication with his/her students, who guides and helps them)

"I expect them to be readers and researchers, and love literature and humans." SP 17 (Teacher who innovates and improves himself)

"First of all, I expect them to work in harmony, organize activities at school with other teachers and cooperate with their colleagues." SP 25 (Teacher with teamwork skills)

"I expect them to deliver their classes regularly, come to school and not use casual leave." SP 17 (Teacher with work discipline)

"First of all, I expect them to create a caring and considerate classroom environment. I prefer them not to have any problems, especially in classroom management." SP 16 (Teacher who is successful at class management)

The opinions of school managers in regard to the "Raising language and literature students who are sensitive towards their country, those around them, culture and art" main theme are as follows:

"Turkish language and literature teachers are the focal point of the cultural life of the school. In the classroom, they have to be a master and a drama artist. Imposing love for reading, going to theatre, and listening to poems are in the hands of teachers..." SP 15 (Transforming language-literature education into art education)

"Teachers must bring the humanist feelings of students to the fore with the activities that they would perform." SP 15 (Raising considerate students)

"They should raise students who are leaders in cultural activities and love their language, country and people." SP 6 (Raising students who love and appreciate their country; raising students who are active in cultural activities)

The opinions of school managers as regards "Realising technology-assisted and student-oriented language and literature education" main theme are as follows:

"They should be teachers who are student-oriented, avoid rote learning and educate their students based on the realities of modern society." SP 21 (Performing student-centred education)

"Teachers have to be active in extra-class activities and share with their students." SP 16 (Performing extra-class activities)

"Turkish language and literature teachers must be versatile. They must make the effort to make the class enjoyable and interesting and should be able to use all kinds of technologies in their classes." SP 11 (Utilizing technology in classes; making classes more enjoyable)

The opinions of school managers in regard to the "Raising language and literature students who have highlevel thinking skills" main theme are as follows: 
"I expect that they ensure that students understand the importance of reading so as to express themselves better and display concrete products by utilizing their creativity and imagination." SP 7 (improving the creativity of students)

\begin{abstract}
"They must be teachers who impart the love for reading and researching to our children. For example, they must raise students who are able to compare world literature and Turkish literature." SP 21 (Raising students with research skills)

"I expect that they raise students who read and discuss, interpret and convey to others what they read." SP 23 (Student with discussion-interpretation power)

"I would prefer to raise students who are strong in literature and communication." SP 25 (Raising students with effective communication skills)
\end{abstract}

In conclusion, the qualitative and quantitative findings of the study are given above. In this context, the technology usage and management skills of teachers were evaluated on the basis of their opinions and the views of school managers within the framework of the professional qualifications of Turkish language and literature teachers. The interpretations of researchers in regard to the findings are presented below in association with the literature (conclusion and discussion).

\title{
CONCLUSION, DISCUSSION AND RECOMMENDATIONS
}

The conclusions of the study can be summarised as follows:

- The language and literature teachers who participated in the study have the opinion that using technology in education is necessary and even very necessary.

- Significant differences were not observed according to the demographic characteristics of the teachers who participated in the study (age, experience, gender etc.) in regard to the necessity of using technology in education.

- The expectations of school managers from language and literature teachers were evaluated and only a limited number of managers (only 1 student out of 26) emphasised that teachers should be competent in using technology.

When the research findings are discussed, the following can be claimed: in a course such as language and literature where communication, interaction and various skills are at the forefront, it is essential that teachers create a learning environment with multiple stimulants (Göçer, 2010; Hayran, 2010; Turhan, 2016). Thus, in this study, teachers answered "necessary" and "very necessary" to the questions related to the use of technology in education. With a constructivist learning approach, teaching methods which ensure that students are actively involved in the learning process have replaced the teaching methods that give students a passive role (Alvarez, 2012; Guo, 2011). Thus, using methods and techniques which result in high-level thinking such as criticism, interpretation, analysis and synthesis in Turkish classes play an essential role in the realisation of the course objectives (Aslan, 2010). Some measures which can increase effectiveness must be taken into consideration while performing activities based on the constructivist approach. For example, the constructivist approach does not approve of Turkish teachers only covering the topics in the coursebook without paying any attention to the interests and needs of students. Whereas written instruments-tools were preferred in Turkish teaching in the past, today, as a result of technological developments, instruments such as pictures, film strips, projectors, radio-television, and computers-internet are being used. In constructivism, it is envisaged that these materials are not only used by teachers in the classroom; instead, they should also be used by students and planning should be made cooperatively (Arslan, 2009).

In his study, Çakır (2009) interviewed 35 Turkish language and literature teachers and determined that only one Turkish language and literature teacher used technology in the classroom. In the same study, only $2.8 \%$ of the opinions given by teachers indicated that technology usage is applied in the classroom to make students active and to encourage them to think. Additionally, teachers presented the problems they experienced while using methods and techniques based on constructivism; however, they did not think that the lack of computers and the Internet would be a problem for students $(1.7 \%)$. In regard to how constructivist methods and techniques could be used more intensely in classrooms, a limited number of teachers $(10.6 \%)$ stated that "technological means in the classroom should be improved".

In his study, Arslan (2008) found that teaching technologies and materials are not adequately used in Turkish classes and behaviours suitable for constructivist process are only partially displayed. In Karadüz's research (2010), it was concluded that teachers continued to apply the behaviourist approach from many perspectives in the learning environments of Turkish classes and did not give any consideration to constructivism. In the study conducted by Arslan, Orhan and Kırbaş (2010), school managers stated that the constructivist learning approach 
was only partially applied in Turkish classes and that Turkish language teachers only partially performed the roles ascribed to them by the constructivist approach. Based on the findings of this study, it is evident that although teachers indicated that using technology is highly necessary, they still could not realise the required transformation in their classrooms or courses and that they could not deliver technology-assisted language and literature courses. Teachers may be inclined to perceive technology as a risky and potentially problematic instrument and disregard the benefits of technology so as not to harm their students. For example, the study conducted by Yaman and Erdoğan (2007) concluded that communication technologies in Turkish teaching weakened the writing and composition skills of students, that language was used haphazardly and carelessly, abbreviations and speaking language elements were used in spelling, and Turkish language was degenerated in terms of "phonetic", "syntax" and "spelling". These are the reasons why a teacher who experiences these problems refrains from using computers in his/her classes. Attempts should therefore be made to solve these problems and use technology effectively in the teaching-learning process.

The following conclusions can be made based on the qualitative data of the study. According to the results of this study, school managers do not expect language and literature teachers to be competent in technology. This is due to the fact that school managers themselves are not competent or interested in technology; thus, it could be the case that school managers do not expect teachers to be competent in technology as they themselves are not highly competent. However, studies conducted on technology leadership show that school managers should follow innovative technological developments and take the lead in their application in order to be defined as a "technology leader" (Çakır, 2013; di Benedetto, 2006, Gökoğlu, 2014). Thus, school managers should lead teachers first so that teachers can manage and use technology. School managers have to possess technological skills, ensure that technology is effectively used in schools and should be able to integrate technology with other managerial areas. According to Banoğlu (2011), a school manager who is a technology leader is also an effective education and teaching leader who facilitates the integration of education with technology, efficiently uses existing school resources in order to acquire education and management technologies and creates additional resources when necessary, closely monitors the command of teachers in education technology and their professionals development in that field, monitors and evaluates in technological media the teaching activities and student achievements at their school, and gives sufficient consideration to the technological means of communication in school-environment interaction.

Based on the findings of the study, the following recommendations are offered:

- Teachers must accept the reality that even though they agree that technology is necessary, this opinion in fact has no value as technology is still not used.

- Even the level of education, in other words having a graduate degree or the age of the teacher (being a recent graduate) do not make any significant difference in terms of technology usage. Thus, awareness should be given on technology-assisted education during graduate education. Updating teacher education programmes is also essential, as even recently graduated teachers lack the required professional competencies for using technology.

In-service training of school managers is also very essential. It is the management philosophy of teachers which determines whether all teachers in a given school improve themselves in the field of technology and are inclined towards using technology. In this context, education policies should be formed which envisage that on-the-job training activities begin with school managers and that every school manager becomes a technology leader.

\section{REFERENCES}

Akkoyunlu, B. \& Soylu, M. Y. (2011). Sosyal iletişim ağları ve dilin yanlış kullanımı üzerine nitel bir çalışma. İlköğretim Online, 10(2), 441-453.

Aksoy, H. H. (2003). Eğitim kurumlarında teknoloji kullanımı ve etkilerine ilişkin bir çözümleme. Eğitim, Bilim, Toplum. 1(4), 4-23.

Akyol, H. (2007). Görsel okuma ve yazma. İlköğretimde Türkçe Öğretimi (Edt. Hayati Akyol-Ahmet Kırkkılıç). Ankara: PegemA Yayıncilik.

Altınok, Ş. (2011). Türk dili ve edebiyatı öğretmen adaylarının eğitimde teknoloji kullanımına yönelik tutumlarının değerlendirilmesi. Eğitim Teknolojileri Araştırmaları Dergisi, 3(2). Retrieved from www.et-ad.net

Alvarez, O. H. (2012). Constructivism and ICT: An experience in the area of language arts with elementary school students. In International Symposium on Computers in Education (SIIE), IEEE, (pp. 1-7).

Arslan, A. (2008). Yapılandırmacı öğrenme yaklaşımına göre hazırlanan Türkçe dersi öğretim programının uygulanmasına ilişkin öğretmen görüşlerini değerlendirilmesi. Unpublished PhD Thesis, Atatürk Üniversitesi Sosyal Bilimler Enstitüsü, Erzurum. 
Arslan, A. (2009). Yapılandırmacı öğrenme yaklaşımı ve Türkçe öğretimi. Atatürk Üniversitesi Sosyal Bilimler Enstitüsü Dergisi, 13(1), 143-154.

Arslan, A., Orhan, S. \& Kırbaş, A. (2010). Türkçe dersinde yapılandırmacı öğrenme yaklaşımının uygulanmasına ilişkin yönetici görüşleri. Atatürk Üniversitesi Sosyal Bilimler Enstitüsü Dergisi. 14(1), 85-100.

Aslan, C. (2010). Düşünme becerilerini geliştirici dil ve edebiyat öğretimi ortamları-Bir eğitim durumu örneği. Balkesir Üniversitesi Sosyal Bilimler Enstitüsü Dergisi, 13(24), 127-152.

Baki, Y. \& Karakuş, N. (2012). Türkçe öğretiminde öğretim teknolojileri ve materyal tasarımı. Ankara: PegemA Yayıncılık.

Balc1, A. (2001). Etkili okul ve okul geliştirme. Ankara: PegemA Yayıncılık.

Banoğlu, K. (2011). Okul müdürlerinin teknoloji liderliği yeterlikleri ve teknoloji koordinatörlüğü. Kuram ve Uygulamada Eğitim Bilimleri, 11(1), 199-213.

Başaran, İ. E. (2000). Eğitim yönetimi nitelikli okul. Ankara: Feryal Matbaası.

Bogdan, R. C. \& Biklen, S. K. (2006). Qualitative research for education: An introduction to theory and methods, (5th edition). Boston: Allyn \& Bacon.

Can, T. (2003). Bolu orta öğretim okul yöneticilerinin teknolojik liderlik yeterlikleri. The Turkish Online Journal of Educational Technology, 2(3), 94-107.

Creswell, J., \& Plano Clark, V. (2007). Designing and conducting mixed methods research. Thousand Oaks, CA: Sage.

Çakır, B. (2009). Türk dili ve edebiyatı öğretmenlerinin kullandıkları yöntem ve tekniklerin yapılandırmacı yaklaşım açısından değerlendirilmesi: Trabzon örneği. Unpublished Thesis, Karadeniz Teknik Üniversitesi Sosyal Bilimler Enstitüsü, Trabzon.

Çakır, R. (2013). Okullarda teknoloji entegrasyonu, teknoloji liderliği ve teknoloji planlaması. In K. Çağıltay \& Y. Göktaş (Eds.), Öğretim teknolojilerinin temelleri: Teoriler, araştırmalar, eğilimler (s. 397-412). Ankara: Pegem Akademi Yayıncilık.

di Benedetto, R. (2006). How do independent school leaders build the educational technology leadership capacity of the school? A multi-site case study. Unpublished doctoral dissertation, Drexel University, United States.

Dias Caetano, L. M., \& Nogueira do Nascimento, M. M. (2017). Integration of digital resources in elementary education. Revista Educaonline, 11(3), 15-32.

Durmuşçelebi, M. (2007). Türkiye ve Almanya'da ilköğretimde anadili öğretimi eğitim programları ve ders kitapları açısından bir karşılaştırma. Unpublished PhD Thesis, Ankara Üniversitesi Sosyal Bilimler Enstitüsü, Ankara.

Durukan, E. (2011). İlköğretim 6. sınıfta bilgisayar destekli dil bilgisi öğretiminin başarı ve tutuma etkisi. Unpublished PhD Thesis, Atatürk Üniversitesi Eğitim Bilimleri Enstitüsü, Erzurum.

Evans, J. A. (1970). Educational management information systems: Progress and prospectives. ERIC Document Reproduction Service, No: ED 049564.

Flanagan, L., \& Jacobsen, M. (2003). Technology leadership for the twenty-first century principal. Journal of Educational Administration, 41(2), 124-142. https:/ / doi.org/10.1108/09578230310464648

Glesne, C. (2011). Becoming qualitative researchers: An introduction, (4th edition). Boston, MA: Pearson.

Güneyli, A. \& Özgür, B. (2007). Technology use in language teaching: The case of foreign language teaching in TÖMER, ERIC Document ED500158, In 7th International Education Technology Conference, 3-5 May, Near East University, Nicosia-North Cyprus.

Güneyli A., Birikim, Ö. and Zeki-Perkan, C. (2009). Computer use in foreign language teaching: A case study from North Cyprus. Eurasian Journal of Educational Research, 34, 37-54.

Göçer, A. (2010). Türkçe öğretiminde çok uyaranlı bir öğrenme ortamı oluşturmak için seçkin edebî ürünlerden yararlanma. Türklük Bilimi Araştırmaları, 27(27), 341-369.

Gökoğlu, S. (2014). Sistem tabanlı teknoloji liderliği modeliyle öğrenme ortamlarna teknoloji entegrasyonunun değerlendirilmesi. Unpublished Thesis, Karadeniz Teknik Üniversitesi, Trabzon.

Guo, Q. (2011). On Problems and Countermeasures of Web-Based Language Teaching from the Perspective of Constructivism. In Education and Educational Technology (pp. 843-848). Springer, Berlin, Heidelberg. https:/ / doi.org/10.1007/978-3-642-24775-0_129

Hayran, Z. (2010). Çok uyaranlı eğitim ortamlarının öğrencilerin kavram gelişimine etkisi. Eğitim ve Bilim, 35(158).

Johnson, R. B., Onwuegbuzie, A. J., \& Turner, L. A. (2007). Toward a definition of mixed methods research. Journal of Mixed Methods Research, 1(2), 112-133. https:/ / doi.org/10.1177/1558689806298224

Kabadayı, O. (2006). Ağ ortamındaki Türkçeye genel bir bakış. Türk Dili, Dil ve Edebiyat Dergisi, 652, 298-314. 
Karadüz, A. (2010). Yapılandırmacı paradigma bağlamında Türkçe derslerinde öğrenme ortamları. Mustafa Kemal Üniversitesi Sosyal Bilimler Enstitüsü Dergisi, 7(14), 135-154.

Karasar, N. (2015). Bilimsel araştırma yöntemi (28. baskı). Ankara: Nobel Yayın Dağıtım.

Kearsley, G. \& Lynch, V. (1992). Educational leadership in the age of technology: The new skills. Journal of Research on Computing in Education, 25(1), 1-9. https:/ / doi.org/10.1080/08886504.1992.10782032

Lawrence, J. E. (2018). Factors influencing teachers' integration of ICT in teaching and learning. International Journal of Adult Vocational Education and Technology (IJAVET), 9(2), 48-63. https:/ / doi.org/10.4018/IJAVET.2018040104

Lin, S. Y. (2016). The use of technology in K-12 Schools: Demystifying the relationship between technology leadership and technology use (Doctoral dissertation, The Ohio State University).

Maxwell, J. A. (1996). Qualitative research design: An interactive approach. Thousand Oaks, CA: Sage Publications.

Melo, L. M., Mendez Batres, J. M., \& Martinell, A. R. (2017). Integrating an innovative learning model as ICT support in the language area. Revista de Investigacion Educativa de la Escuela de Graduados en Educacion, 7(14), 26-32.

Miles, M. B. \& Huberman, A. M. (1994). Qualitative data analysis (2nd edition). Thousand Oaks, CA: Sage Publications.

Mooij, T., \& Smeets, E. (2001). Modelling and supporting ICT implementation in secondary schools. Computers $\mathcal{E}$ Education, 36(3), 265-281. https:/ / doi.org/10.1016/S0360-1315(00)00068-3

Nurova, L. A., Kharisov, F. F., Kharisova, C. M., \& Aitova, N. N. (2017). Innovations in Turkic language teaching under conditions of polyilinguism. Revista Publicando, 4(13(1)), 671-680.

Osmani, M., Hindi, N. M., \& Weerakkody, V. (2018). Developing employability skills in information system graduates: Traditional vs. innovative teaching methods. International Journal of Information and Communication Technology Education (IJICTE), 14(2), 17-29. https:/ / doi.org/10.4018/IJICTE.2018040102

Öner, T. (2006). Bilişimde özenli Türkçenin önemi. Bilişim ve Bilgisayar Mühendisliği Dergisi, 1(1). Retrieved from www.site.uottawa.ca/ oren/pubs/2005/T02-02-BOTO.pdf

Önkaş, N. A. (2010). Türkçe eğitiminde teknoloji kullanımı ve kalıcı öğrenme. Eğitim Teknolojileri Araştırmaları Dergisi, 1(2). Retrieved from www.et-ad.net

Özbay, M. (2003). Öğretmen görüşlerine göre ilköğretim okullarında Türkçe öğretimi. Ankara: Gölge Ofset Matbaacılık.

Özbay, M. (2015). Yeni eğitim yaklaşımlarının Türkçe öğretiminde uygulanması. Ankara: Öncü Kitap.

Pala, A. (2006). İlköğretim birinci kademe öğretmenlerinin eğitim teknolojilerine yönelik tutumları. Manas Üniversitesi Sosyal Bilimler Dergisi, 16, 177-188.

Petko, D., Prasse, D., \& Cantieni, A. (2018). The interplay of school readiness and teacher readiness for educational technology integration: A structural equation model. Computers in the Schools, 35(1), 1-18. https:/ / doi.org/10.1080/07380569.2018.1428007

Rodríguez, J. C. (2018). Redesigning technology integration into world language education. Foreign Language Annals, 51(1), 233-239. https:/ / doi.org/10.1111/flan.12328

Salimi, L., \& Ghonoodi, A. (2012). The study of functional elements of management system in smart schools. Procedia-Social and Behavioral Sciences, 31, 140-144. (World Conference on Learning, Teaching \& Administration, WCLTA 2011)

Schiller, J. (2003). Working with ICT: Perceptions of Australian principals. Journal of Educational Administration, 41(2), 171-185. https:// doi.org/10.1108/09578230310464675

Shyr, W. J. (2017). Developing the principal technology leadership competency indicators for technical high schools in K-12 in Taiwan. Eurasia Journal of Mathematics, Science and Technology Education, 13(6), 2085-2093. https:/ / doi.org/10.12973/eurasia.2017.01215a

Sinchi Barbecho, W. A., Torres Pineda, J. C., \& Alvarado Salinas, Y. C. (2017). Impact of information and communication technologies in the educational field. Revista Conrado, 13(59), 199-205.

Şahin, A. \& Akçay, A. (2011). Türkçe öğretmeni adaylarının bilgisayar destekli eğitime ilişkin tutumlarının incelenmesi. Turkish Studies, 6(2), 909-918.

Telem, M. (1999). A case of the impact of school administration computerization on the department head's role. Journal of Research on Computing in Education, 31(4), 385-401. https:/ / doi.org/10.1080/08886504.1999.10782261

Temur, T \& Vuruş, N. (2009). İnternet (genel ağ) ortamında Türkçenin kullanımına ilişkin bir çözümleme. Balıkesir Üniversitesi Sosyal Bilimler Enstitüsü Dergisi, 12(22), 232-244. 
Turhan, H. (2016). Çok uyaranl eğitim ortamlarını öğrencilerin okuduğunu anlama ve yazılı anlatım becerilerine etkisi. Unpublished PhD Thesis, Ankara Üniversitesi Eğitim Bilimleri Enstitüsü, Ankara.

Weng, C. H., \& Tang, Y. (2014). The relationship between technology leadership strategies and effectiveness of school administration: An empirical study. Computers $\mathcal{E}$ Education, 76, 91-107. https:/ / doi.org/10.1016/j.compedu.2014.03.010

Yaman, H. \& Erdoğan, Y. (2007). İnternet kullanımının Türkçeye etkileri: Nitel bir araştırma. Journal of Language and Linguistic Studies, 3(2), 237-249.

Yıldırım, F. \& Tahiroğlu, B. T. (2006). İnternette Türkçe kullanımı sorunları. Türkçenin çă̆daş sorunları. G. Gülsevin ve E. Boz (Eds.), 2. Baskı, Ankara: Gazi Kitabevi, 359- 378.

Yıldırım, A. \& Şimşek, H. (2011). Sosyal bilimlerde nitel araştırma yöntemleri (8. Baskı). Ankara: Seçkin Yayıncılık.

Yuen, A. H. K., Law, N. \& Wong, K. C. (2003). ICT implementation and school leadership: Case studies of ICT integration in teaching and learning. Journal of Educational Administration, 41(2), 158-170. https:/ / doi.org/10.1108/09578230310464666

http://www.ejmste.com 